\title{
COMPENSATION AND THE SCOPE OF EQUITY's Remedial AND Restitutionary Generosity
}

\author{
PAul M. PERell'
}

Canson Enterprises Ldd. v. Boughton is a case abous equity's restitutionary remedies, including compensation for breach of Nduciary duty and compensation under the doctrines of knowing assistance and knowing receipl. II was an unusual civil case because "t had two distinct phases that ylelded two trial level judgments, two judgments of the British Columbia Court of Appeal, and an important judgment from the Supreme Court of Canada. The Canson case was extraordinary because there were significant changes from phase one to phase two in the foctual foundaston of the case, and these changes provided a novel opportunity to study the nature of equilable remedles and to develop instructive comparisons and contrasts. This article uses the Canson case as $a$ vehicle to explore equitable compensation and the scope of equity's remedial and restitutionary generosity.
La cause Canson Enterprises Lid. c. Boughton \& Co. iraite des redressements de restitution fondes sur lëquite - notamment l'indemnisation pour manquement d une obligation fiduciaine et l'indemnisation fondee sur les principes d'aide ou de riception apporté en connaissance de cause. II s'agit d'un cas civil inhabituel, traite en deux temps - et qui a donné lieu à deux jugements de la Cour d'appel de la Colombie-Brirannigue et à un jugement important de la Cour suprème du Canada. Le cas est exceptionnel parce qu'il y a eu, d'une instance $a$ l'autre. des changements importants qui ont permis dërudier la nature des redressements fondes sur l'íquiré at d'ürablir des comparaisons ef des contrastes instructifs. L'auteur s'appuie sur la cause Canson pour examiner l'indemnisation équilable el la portée de la genérosité aux fins de réparation el de restitution fondèe sur l'équité.

\section{TABle of CONTENTS}

I. IntRodUCtION $\ldots \ldots \ldots \ldots \ldots \ldots \ldots \ldots \ldots \ldots \ldots \ldots \ldots$

II. CANSON ENTERPRISES LTO. V. BOUGHTON -

The Procedural History and an OVerview of the FACTS . . 116

III. THE SCOPE of EquITABle COMPENSATION $\ldots \ldots \ldots \ldots \ldots \ldots 119$

IV. RECOVERY OF SECRET PROFITS AND THE

Claims for Knowing assistance $\ldots \ldots \ldots \ldots \ldots \ldots \ldots \ldots 123$

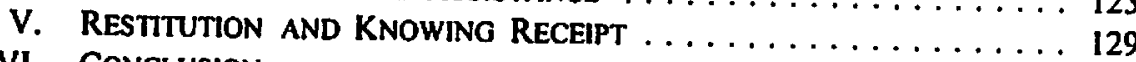

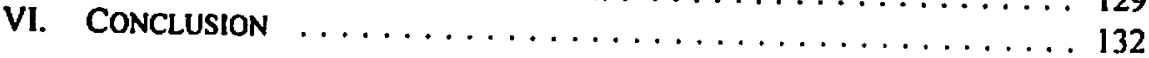

\section{l. INTRODUCTION}

Equity's power to remedy financial harm by an award of damages or what is called compensation in equity has been the subject of several recent important judgments that have drawn attention to equity's capabilities and its remedial and restitutionary generosity. The recent cases show that litigants with claims for damages for negligence or breach of contract often join these common law claims with equitable claims for compensatory, proprietary, or restitutionary remedies for breach of trust, breach of fiduciary duty, liability for unjust enrichment,' liability as a trustee de son fort, liability

D. Jur., Weir \& Foulds, Toronto, Ontario.

Strictly speaking, the modem claim for unjust enrichment is rooted in both equity and the common law but it is usually referred to as an equitable claim. See, P.M. Perell, The Fusion of Law and Equity (Toronto: Butterworths, 1990) at 113-28. 
for knowing assistance, or liability for knowing receipt. The litigants are motivated to add these equitable claims because the reach of equity's remedies may capture more defendants and the equitable remedies may be more substantial and valuable than the remedies available under the common law, and where there is concurrent liability, the injured party may sue in whatever manner he finds most advantageous. ${ }^{2}$ However, some of the judgments have also struggled to restrain equity from going beyond what is fair treatment of the guilty defendant ${ }^{3}$ or from interfering with the claims of third parties. ${ }^{4}$

The aim of this article is to use one of the recent cases, Canson Enterprises Ltd. v. Boughton, as a vehicle to examine what the contemporary caselaw has revealed about the scope of equity's remedial generosity when a court exercises its equitable jurisdiction to award compensation. Canson presents several examples of equity's generosity in making monetary awards, considers the limits to that generosity, and offers unique and rich opportunities to explain both rudimentary and very subtle points about the operation of equity's remedies. ${ }^{6}$ Canson is very instructive. The approach of

2 Central Trust Co. v. Rafuse (1986), 3I D.L.R. (4th) 481 (S.C.C.) (choice between tor and contract); Nocton v. Lord Ashburton, [1914] A.C. 932 (H.L.) (hereinafter Nocion] (choice between law and equity).

3 This struggle to control the scope of an equitable remedy that may be more advantageous than the associated common law remedy has also recently been played out in cases that have changed the law about the availability of specific performance in lieu of common law damages. The traditional position was that the equitable remedy of specific performance was available as a matter of course for the breach of a contract for the sale of land: Kloepfer Wholesale Hardware and Automotive Co. Lid. v. R.G. Roy, [1952] 2 S.C.R. 465; Bashir v. Koper (1983), 40 O.R. (2d) 758 (C.A.). A consequence of the traditional position was that plaintiff purchasers could capture inflationary increases in land values by suing for specific performance. The recent cases, however, hold that the plaintif must justify the remedy of specific perfornance by showing that the land is unique or by showing in some other way that common law damages are inadequate: Semelhago $v$. Paramadevan, [1996] 2 S.C.R. 415; Domowicz v. Orsa Investments Lid. (1993), 36 R.P.R. (2d) 174 (Gen. Div.), additional reasons (1993), 15 O.R. (3d) 661 (Gen. Div.) and (1994), 20 O.R. (3d) 722 (Gen. Div.), arrd [1998] O.J. No. 452 (C.A.) (QL).

- This struggle to control the scope of an equitable remedy can also be seen in recent cases that have considered the appropriateness of proprictary remedies for breach of liduciary duty and unjust enrichment. See LAC Minerals Lid. v. Imernational Corona Resources Lsd. (1989), 61 D.L.R. (41h) 14 (S.C.C.); Peter v. Beblow (1993), 101 D.L.R. (4(h) 621 (S.C.C.); Nuforest Watson Bancorp Lid. v. Prenor Trust Co of Canada (1994), 21 O.R. (3d) 328 (Gen. Div.); Barnabe v. Touhey (1995), 26 O.R. (3d) 477 (C.A.). Factors relevant to whether a proprietary remedy is justified include: the appropriateness of the plaintiff having a protected claim in a bankruptcy; the appreciation or diminishment in value of the property; whether the defendant intercepted the plaintifrs opportunity; the moral quality of the defendant's act; the adequacy of other remedies, including difficulties in assessment; and the uniqueness of the property.

s (1988), 52 D.L.R. (4th) 323 (B.C.S.C.) [hereinafler Canson], aff d (1989), 61 D.L.R. (4th) 732 (B.C.C.A.), alrd (1991), 85 D.L.R. (4th) 129 (S.C.C.); consequent assessment of damages [1993] I W.W.R. 386 and [1993] 4 W.W.R. 194 (B.C.S.C.), aff d [1996] I W.W.R. 412 (B.C.C.A.), leave to appeal to the Supreme Court of Canada refused March 26, 1996.

- See also: J.D. McCamus. "Prometheus Unbound: Fiduciary Obligation in the Supreme Court of Canada" (1997) 28 Can. Bus. L.J. 107; L.D. Roebuck. "Prometheus Unbound: A Practitioner's Perspective" (1997) 28 Can. Bus. L.J. 155; S. Hoegner, "How Many Rights (or Wrongs) Make a Remedy? Substantive, Remedial and Unified Constructive Trusts" (1997) 42 McGill L.J. 437; S. M. Waddams, "Fiduciary Duties and Equitable Compensation" (1996) 27 Can. Bus. L.J. 466; J.D. 
the article will be to begin with an overview of its procedural history and of its facts. This overview will be followed by a discussion of some of the major issues raised by the case. The discussion of Canson will prompt some brief comments about $R$. v. Guerin ${ }^{7}$ and about the recent decision of the Supreme Court of Canada in Hodgkinson v. Simms ${ }^{8}$ and some more extensive comments about the Re Air Canada and $M \& L$ Travel Ltd. ${ }^{9}$ line of cases, ${ }^{10}$ of which the Air Canada case played a prominent role in the Canson case. All of these cases involve claims for monetary awards that may not have been available under the common law.

\section{CANSON ENTERPRISES LTD. V. BOUGHTON \\ - THE PROCEdural HISTORY aNd aN OVERVIEW of the Facts}

To understand the richness of the lessons from Canson Enterprises Lid. v. Boughton, it is helpful to begin with its cast of characters and an overview of its procedural history. The plaintiffs Canson Enterprises Ltd. and Fealty Enterprises Ltd. sued Peregrine Ventures Inc. for, among other things, breach of contract. Peregrine was their joint venture partner in the purchase of lands for a mini-warehouse project that turned out to be a financial disaster. The plaintiffs also sued Ralph Wollen, their solicitor, and his law firm, Boughton \& Co. However, they did not directly sue Wollen's partner, James Boughton, although Boughton was involved in the action as the principal of Peregrine and as a member of the defendant law firm. Further, the plaintiffs advanced claims against Gordon Wilkins and his company, Sun-Mark Development Corporation, and against George Treit and his companies, Treit Land Consultants Inc. and Pacific Mortgage Corporation Limited. The claim against the Wilkins and Treit groups was for the disgorgement of a secret profit that these defendants had made on the joint venture's purchase of the warehouse lands.

The action proceeded in two phases. In the first phase, the parties agreed to state a case on the basis of assumed facts. They did this to obtain a ruling about what heads of damages were recoverable against the several classes of defendants. In this phase the most problematic claim was against Wollen and his law firm. The first phase yielded judgments from the British Columbia Supreme Court (Macdonell J.), from the British Columbia Court of Appeal (Carruthers, Lambert, and Hutcheon JJ.A.), and from the

McCamus, "Equitable Compensation and Restitutionary Remedies: Recent Developments" in Law Socieny of Upper Canada Special Lecrures (Toronto: Carswell, 1995) 295; L. Smith, "Fiduciary Relationships - Arising in Commercial Contexts - Invesument Advisors: Hodgkinson v. Simms" (1995) 74 Can. Bar Rev. 714; J.D. Davies, "Equitable Compensation: Causation, Foreseeability and Remoteness" in D.W.M. Waters, ed., Equity, Fiduciaries and Trusis (Toronto: Carswell, 1993) 297; Gummow J., "Compensation for Breach of Fiduciary Duty" in T.G. Youdan, ed., Equity, Fiduciaries and Trusts (Toronto: Carswcll, 1989) 57; P.M. Perell, "The Aftermath of Fusion: Canson Enterprises Lid. v. Boughton and Co." (1993) 14 Adv. Q. 488; N. Rafferty, "Developments in Contract and Tort Law: The 1991.92 Term" (1993) 4 Supreme Court L.R. (2d) 329.

(1984), 13 D.L.R. (4th) 321 (S.C.C.).

(1994), 117 D.L.R. (4th) 161 (S.C.C.) [hereinafter Hodgkinson].

(1993), 108 D.L.R. (4th) 592 (S.C.C.).

Gold v. Rosenberg (1997), 152 D.L.R. (4th) 385 (S.C.C.); Citadel General Assurance Co. v. Lloyds Bank Canada (1997), 152 D.L.R. (4th) 4l] (S.C.C.) [hereinafter Citadel]. 
Supreme Court of Canada (Lamer C.J.C., Wilson," La Forest, L'Heureux-Dubé, Sopinka, Gonthier, Cory, McLachlin, and Stevenson JJ.). Informed by the legal advice obtained in the first phase, the action moved to its second phase which was a trial where some of the facts assumed in the first phase were put to actual evidentiary proof. Paris J. of the British Columbia Supreme Court, the trial judge for the second phase, noted that he had to make his own findings of fact, liability and assessment of damages, and these might produce results that differed from those of the first phase. The second phase yielded judgments from Paris J. and from the British Columbia Court of Appeal (Hinkson, Rowles, and Donald JJ.A.), and its results were indeed somewhat different from those of the first phase. Analyzing the differences between the results of the first and second phase provides a unique and instructive opportunity.

The factual background to Canson is as follows. ${ }^{12}$ Wilkins' company, Sun-Mark, purchased a property from the Hendersons for $\$ 410,000$. Wilkins had a business relationship with Treit, who was an officer but not an owner of Canson. Treit put together a transaction in which Canson (as to a 50 percent interest), Fealty (as to a 25 percent interest) and Peregrine (as to a 25 percent interest) purchased the Henderson property for $\$ 525,000$. In this transaction, the owners of Canson and Fealty thought they were purchasing directly from the Hendersons and were unaware of Sun-Mark's intervening purchase. Peregrine, through its owner, Boughton, however, did know about Sun-Mark's "flip" of the property, but he did not disclose this knowledge to his joint venturers, nor did he disclose his knowledge that Treit was sharing in the $\$ 115,000$ profit being made on the intervening transaction. Boughton, who was a lawyer, retained his own law firm, Boughton \& Co., to document the joint venture and to close the transaction. Wollen, Boughton's partner, took carriage of the matter. Wollen, who learned about the intervening transaction to Sun-Mark, did not disclose this information to his clients, Canson and Fealty, although he had good reason to doubt whether Canson, and more particularly, Fealty, knew about the circumstances of this intervening purchase. The transaction closed with a deed conveying directly from the Hendersons. According to the assumed facts of the first phase and, later, as a finding of fact in the second phase, Canson and Fealty would not have entered into the joint venture and purchased the property had they known of the intervening purchase by Sun-Mark.

Pausing here, two important factual differences between the first phase and the second phase of the action should be emphasized. One difference was that for the first phase, it was assumed that Wollen knew that Canson and Fealty were unaware of the intervening purchase and that Wollen did not disclose that the Hendersons were receiving only $\$ 410,000$, while for the second phase, Paris J. accepted Wollen's evidence that he mistakenly thought all the joint venturers knew about the intervening transaction. The other difference was that in the first phase, it was assumed that Wollen knew that Treit was sharing the secret profit, while for the second phase, Paris J. accepted Wollen's evidence that while he knew about the intervening transaction, he did

"Wilson J. took no part in the judgments.

12 This summary ignores a second transaction known as the Phillips transaction, but the Phillips transaction raised the same legal problems and can be ignored without doing any harm to the analysis of the Canson case. 
not know that it involved a secret profit. The legal significance of these factual differences will be revealed below, but it can immediately be noted that a defendant's state of knowledge is an important factor for a court of equity and here Wollen's knowledge is different for each version. For the first phase version, Wollen knew his clients were unaware of the intervening transaction and the secret profit, but he did not inform them; while for the second phase version, Wollen did not know what his clients knew about the intervening transaction, but did not think to confirm their state of knowledge. In the second phase version, Wollen had no reason to disclose the secret profit because he was ignorant of it.

Retuming to the factual background, after the transaction closed, Canson, Fealty, and Peregrine proceeded to develop the Henderson property. They hired contractors to build a mini-warehouse project. The project, however, was ill-fated, and the joint venture suffered substantial losses when the foundations supporting the structure failed and the warehouses began to sink. Canson and Fealty sued the soils engineer and the pile-driving contractor. After a trial and an appeal, the engineer was found liable in negligence and the pile-driving contractor was found liable for breach of contract. Unfortunately, the engineer and the pile-driving contractor did not have the financial means or the insurance coverage to pay the total judgment for the losses on the warehouse project and Canson and Fealty's share of the shortfall was approximately $\$ 1.1$ million. Their venture collapsed and the Henderson property was lost through foreclosure. They now looked for somebody else to make them whole.

In Canson Enterprises Lrd. v. Boughton, Canson and Fealty sued for their losses not recovered from the engineer and pile-driving contractor. Before analyzing the plaintiffs' claims and the equitable remedies available to them, it is necessary to pause again to emphasize another significant factual difference between the first and second phases of the action. In the first phase, it was assumed that the Henderson property was worth only $\$ 410,000$, but in the second phase, the evidence established that the property was worth $\$ 495,000$. Thus, only for the first phase version of the facts, the difference between what the plaintiffs paid, that is, $\$ 525,000$, and the land's assumed worth was equivalent to the secret profit acquired by some of the defendants.

The legal significance of the assumption in the first phase that the secret profit was equal to the overpayment for the Henderson's land, is that although the legal basis of liability of the various classes of defendants might differ, their exposure for this particular head of damages would be the same. If the guilty profiteers disgorged their secret profit as the remedy for their breach of fiduciary duty, then the plaintiffs would recover $\$ 115,000$ but would have to account to Peregrine for its 25 percent share, ${ }^{13}$

That Peregrine would not be disqualified from a share of the disgorged secret profit was not discussed in the judgments in Canson, although Paris J. did not allow the plaintiffs to recover for Peregrine's share when he calculated damages for the overpayment of the property. In Olson v. Gullo (1994), 17 O.R. (3d) 790 (C.A.) [hercinafter Olson], the Ontario Court of Appeal considered the question of a guilty fiduciary's entitlement to share in secret profits. Olson was a partnership dispute where one partner breached its duty to the partnership and procured a secret profit. In Olson, the defendant was obliged to disgorge the profit but not its own partnership share of the profit. As Morden A.C.J.O. pointed out, the defendant's taking of his normal share did not involve 
to yield a net recovery of $\$ 86,250$ or if Wollen and his law firm paid compensation for the consequences of their negligence or breach of fiduciary duty, the measure of the plaintiffs' compensation would be their proportionate share of $\$ 115,000$, that is, again $\$ 86,250$. In either event, the plaintiffs' recovery was a proportionate share of $\$ 115,000$ because they could not claim to have suffered from Peregrine's losses. ${ }^{14}$ The relationship between the secret profit and the overpayment for the land is a very interesting feature and needs to be emphasized because this equivalence did not continue into the second phase version of the facts. In the second round, the measure of the secret profit no longer equalled the overpayment for the property, and this change raised the legal question of what justification there was, if any, as against the law firm and Wollen, who did not share in the secret profits, for assessing their liability at more than the plaintiffs' proportionate share of the $\$ 30,000$ overpayment, which was $\$ 22,500$. The answer to this specific legal question is one of the lessons from the second phase. The major lessons from the first phase, however, were the more general ones about the generosity and restitutionary nature of equitable remedies and about whether there are limits on equitable compensation for breach of fiduciary duty. These lessons are the subject of the next part of this article.

\section{II. The SCOPE Of Equitable. COMPENSATION}

In the first phase of Canson Enterprises Lid. v. Boughton \& Co., based on the assumed facts, the plaintiffs' damages were their share of the secret profit or of the $\$ 115,000$ difference between the two selling prices for the Henderson property, and they also claimed what was described as consequential losses arising from the failed warehouse project. The first claim was not contested. The major issue that preoccupied the courts in the first phase was whether and to what extent the various defendants should be liable for the consequential losses, that is, the losses that arose from the legal misdeeds of the soils engineer and pile-driving contractor.

In making a case for liability for the consequential losses, the plaintiffs relied heavily on the Supreme Court of Canada's decision in R. v. Guerin, ${ }^{15}$ a case that involved the federal government's breach of fiduciary duty in administering lands of an Indian band. In Guerin, the government had failed to follow the band's instructions when it negotiated a lease of the reserve lands that were being surrendered for the lease. Restoring the judgment of the trial judge, the Supreme Court held that the band was entitled to compensation measured by a rough calculation of the value of the lost opportunity to make a better retum from the surrendered lands. The court rejected the government's argument that all the band had lost was the difference in value between the lease the government was instructed to obtain and the value of the less favourable lease it had in fact obtained. Instead the court awarded $\$ 10,000,000$ for the lost opportunity to make a greater return from the reserve lands. The calculation of this award was equitable and restitutionary in its approach and similar to an assessment of

any breach of duty.

Paris J. made this point in his supplementary reasons, in Canson cited to [1993] 4 W.W.R. 194 (B.C.S.C.), supra note 5 at 196.

15

Supra note 7. 
damages for breach of trust, where the beneficiary is placed so far as possible in the position as if there was no breach of trust. Further, the award was based on events after the government's breach, including the unforeseen substantial escalation in land values. Dickson J., for himself and three judges, agreed with the approach of the trial judge and said that the damages were to be determined by analogy with the principles of trust law. ${ }^{16}$ In a separate judgment, Estey J. also accepted the trial judge's award. Wilson J., for herself and two judges, also agreed with the approach of the trial judge, and stated that for compensation for breach of fiduciary duty, "considerations of causation, foreseeability and remoteness do not readily enter into the matter."17 The generous approach of equity was to make favourable assumptions for the beneficiary. It would be assumed that had the band been properly advised, it would have wished to develop its lands in the most favourable way during the period covered by the unauthorized lease. It was not necessary to prove that the band actually would have developed the lands; in equity, this would be presumed. ${ }^{18}$

Guerin is a demonstration of equity's remedial and restitutionary generosity and its strictness against guilty trustees of fiduciaries. ${ }^{19}$ In the case, the principles applied for a breach of trust were applied to a breach of fiduciary duty. The federal government had not itself profited from its failure to follow instructions, but a guilty trustee or fiduciary is liable to compensate the beneficiary for losses arising from the breach of trust or fiduciary duty, even though the trustee or fiduciary has not shared in the profits. ${ }^{20}$ In assessing compensation, if a misappropriated or mismanaged asset increases in value, a beneficiary is entitled to have his or her loss calculated at the time of trial rather than at the time of the breach. ${ }^{21}$ The overall approach is restitutionary in the sense of aiming toward restoring the beneficiary to the best position in which he or she might have been had there been no breach of duty.

In Canson, given the fact that they would not have entered into the transaction but for the breach of fiduciary duty, Canson and Fealty relied on Guerin and argued that they should be wholly restored and placed in the position as if there had been no breach. This argument, which would provide compensation for the consequential losses, gathered considerable force because all the courts agreed with the plaintiffs that Wollen

16. Ibid. at 345, Dickson J.

17 Ibid. at 365, Wilson J., quoting from Street J. in Re Dawson: Union Fidelity Trustee Co. v. Perpetual Trustee Co., [1966] 2 N.S.W.R. 211 (S.C.).

in Ibid. at 366-67, Wilson J.

14 "The law of fiduciary duties has always contained within it an element of deterrence:" Hodgkinson, supra note 8 at 208-209, La Forest J. The recent Soulos v. Korkontzilas (1997), 146 D.L.R. (4th) 214 (S.C.C.), afrd (1995), 25 O.R. (3d) 257 (C.A.), rev'd (1991), 4 O.R. (3d) 51 (Gen. Div.), is perhaps the high water mark of equity's solicilousness for beneficiaries and strictness against guilty trustees and fiduciaries. In this case, the defendant Korkontzilas, a real estate agent, surreptitiously and in breach of his fiduciary duty purchased the commercial property that he had been retained to procure for the plaintiff Soulos. A majority of the Ontario Court of Appeal and of the Supreme Court of Canada ordered that Korkontzilas convey the property to the plaintiff. What was remarkable about this ruling is that Soulos had suffered no deprivation and Korkontzilas had enjoyed no unjust enrichment because the commercial property had been a losing business venture. Nocion, supra note 2.

21 Tomkinson v. First Pennsylvania Banking and Trust Co., [1961] A.C. 1007 (H.L.). 
had breached his fiduciary duty and that he was liable even though he did not share in the secret profits. La Forest J. stated that academic writings which suggested fiduciary obligations should be narrowed to situations where the fiduciary may benefit rested on a "misguided sense of orderliness."22 Moreover, the courts agreed with the plaintiffs that equity's approach to compensation was essentially restitutionary and more generous than the common law approach to damages for breach of contract or negligence because equity "aimed at restoring a person to whom a duty was owed to the position in which he or she would have been had the duty not been breached." ${ }^{23}$ However, the argument ultimately did not have enough force; equitable relief was not without its limits. All the courts disagreed with the plaintiffs' conclusion that the measure of Wollen's and the other defendants' liability extended to make them liable for the losses flowing from the faults of the engineer and pile-driving contractor.

The Supreme Court of Canada was unanimous in agreeing with the lower courts that there are limits on equitable compensation. The problem was describing and explaining those limits. There was disagreement about the doctrinal basis for the limits on equity's compensation and about the articulation of the limiting principles. In the Supreme Court, La Forest J., for himself and Sopinka, Gonthier, and Cory JJ., concluded that limiting principles could be borrowed from the common law as a matter of the fusion of law and equity brought about by the various Judicature Acts in England and Canada. For these judges, the desirable approach was to call in aid the system, either the common law or equity, that was better developed to do justice. La Forest J. stated:

Where a situation requires different policy objectives, then the remedy may be found in the system that appears more appropriate. This will oflen be equity. Its nexible remedies such as constructive trusts, account, tracing and compensation, must continue to be moulded to meet the requirements of fairness and justice in specific situations. ${ }^{24}$

La Forest J. concluded that damages equivalent to those for the tort of deceit would be appropriate to sustain the fiduciary relationship without unnecessary harshness on the defendants. This meant that the guilty fiduciary would be liable for both foreseeable and unforeseeable damages flowing from the breach of duty. Going this far, equity's compensation was more generous than would be the recovery of damages for common law negligence, where damages must be foreseeable. However, the recovery in equity stopped where the chain of causation was broken. In Canson, the acts of the engineer and the pile-driving contractor broke the chain of causation. In contrast, in Guerin, the chain of causation from the breach of fiduciary duty had not been broken.

In Canson, Stevenson J. in a short and obscure judgment expressed agreement with La Forest J. but parted company on two points. First, he noted that the measure of compensation in equity may not always be the same as damages for deceit. In his view, the losses caused by the engineer and the pile-driving contractor could not in faimess

24 Ibid. at 153. Sec also La Forest J.'s judgment in Hodgkinson, supra note 8 at 201-203. 
be attributed to the breach of fiduciary duty. Second, he denied that the so-called fusion of law and equity had anything to do with deciding the case.

McLachlin J., for herself, Lamer C.J.C., and L'Heureux-Dubé J., concluded that it was unnecessary and undesirable to move outside of equity's territory to find limiting principles. Consistent with equity's unique goals and foundations and its protection of fiduciary relationships, there were already existing measures, although foreseeability of loss was not one of them. Equity's limiting factors included a common sense view of causation and the refusal to compensate the plaintiff for unreasonable conduct or for unconnected acts by third parties. Conveniently, she summarized equity's approach to compensation for breach of fiduciary duty, including its limiting principles, in the following paragraph of her judgment:

In summary, compensation is an equitable monetary remedy which is available when the equitable remedies of restitution and account are not appropriate. By analogy with restitution, it attempts to restore to the plaintiff what has been lost as a result of the breach, l.e., the plaintifrs lost opportunity. The plaintilf's actual loss as a consequence of the breach is to be assessed with the full benefit of hindsight. Foreseeability is not a concern in assessing compensation, but it is essential that the losses made good are only those which, on a common sense view of causation, were caused by the breach. The plaintiff will not be required to mitigate, as the term is used in law, but losses resulting from clearly unreasonable behaviour on the part of the plaintiff will be adjudged to flow from that behaviour, and not from the breach. Where the trustee's breach permits the wrongful or negligent acts of third parties, thus establishing a direct link between the breach and the loss, the resulting loss will be recoverable. Where there is no such link, the loss must be recovered from the third parties."

Applying these principles to the Canson case, on a common sense view of causation, the losses sustained by the faults of the engineer and the pile-driving contractor were not caused by the breach of fiduciary duty but were caused by decisions made by the plaintiffs after the duty of Wollen and his law firm had come to an end.

Pausing here to reflect upon what the first phase of Canson reveals about equity's remedial and restitutionary generosity, a major lesson is that while equity is solicitous to the victims of breaches of fiduciary duty, there are limits to the compensation for the injury. It does not automatically follow that equity will fully restore the injured party to the position in which he or she would have been but for the defendant's breach of fiduciary duty. However, the limits to equitable compensation are vaguely defined, and it needs to be noted that Canson was arguably an extreme case that seemed to call out for some limits on the exposure of the guilty fiduciary. Had the judgment gone against Wollen and his law firm, they would have been liable for over $\$ 1$ million dollars of losses directly caused by other professionals or contractors. 
Subsequent cases bear out that while Canson provides the guilty fiduciary with some means to fashion an argument to reduce his or her liability, ${ }^{26}$ it will remain very difficult to reduce the quantum of the plaintiff's recovery. Thus, the principles of Canson did not help the defendant in Hodgkinson v. Simms. ${ }^{27}$ Here, the defendant was an investment adviser, who breached his fiduciary duty by failing to disclose his financial relationship with the developer in whose project he had placed the plaintiffs money as a tax shelter. The defendant failed to disclose that he had earned an award from the developer for the placement. The majority of the Supreme Court denied the defendant's argument that, given that the plaintiff had initially received full value for his investment and given that the defendant was not proven to have been negligent, the plaintiff's losses arose not from the defendant's breach of fiduciary duty but from the subsequent downtum in the economy. La Forest J., writing for the majority, stated: "Canson does not, however, signal a retreat from the principle of full restitution; rather, it recognizes the fact that a breach of fiduciary duty can take a variety of forms, and as such a variety of remedial considerations may be appropriate." 28 In Hodgkinson, unlike Canson, the subsequent financial disaster was seen to be sufficiently connected to the advice and services of the guilty fiduciary. The response of the majority was that having placed the plaintiff in an investment that he would not have entertained if properly advised, the defendant exposed the plaintiff to the risks of the marketplace and was liable for the losses. Taken together, Guerin, Canson, and Hodgkinson reveal that, while there are some limits, equity's remedy of compensation for breach of trust or fiduciary duty remains very generous indeed.

\section{Re.covery of Secretr Profits AND the: Claims for KNowing Assistance}

The outcome of the first phase of Canson was that the Supreme Court upheld the lower court judgments. Based on the stated case, the original judgment was that the plaintiffs were entitled to damages for the secret profit or for the overpayment for the Henderson property and to consequential damages excluding those caused by the engineer and pile-driving contractor. ${ }^{29}$ The action returned to the British Columbia Courts for its second phase, the assessment of those damages. However, when Canson returned for this second phase, the evidentiary basis of the case was reopened. Wollen and his law firm seized upon this opportunity and were able to change the factual underpinning for the application of equitable principles as against them. The case against the other defendants, however, did not change. Comparing and contrasting the

Although it was obiter dicta, in Wynne v. William M. Mercer Lid. (1995), 131 D.L.R. (4th) 256 (B.C.C.A.), the British Columbia Court of Appeal held that the administrators of a pension plan, who had seen their plan experience an unnecessary and substantial unfunded liability because of erroneous advice from the defendant actuary, were obliged to mitigate even if the defendant's liability was characterized as a breach of fiduciary duty. Supra note 8.

lbid. at 201.

29 The exact wording of the order was as follows: "This court orders that assuming the facts alleged in the Statement of Claim and in the Statement of Facts of this Special Case are true, the Plaintiffs are entitled to consequential damages and are not limited to the amount of secret profit, but those damages will be limited to those leading up to the negligence of the engineers and pile drivers." 
position of the various defendants provides more lessons about the range and complexities of equity's remedies and about their advantages over common law remedies. In particular, this phase offers interesting lessons about the disgorgement of profits and about the equitable claim for knowing assistance, topics which are considered in this section, and about knowing receipt, which will be considered in the next section of this article.

Based on the findings of fact of the second phase, the defendants could be divided into three classes. The first class was constituted by Peregrine, the corporation owned by Boughton. It had breached its joint venture agreement with the plaintiffs but had not shared in the secret profit. The liability of Peregrine arose in contract, and for the purposes of this article about equitable remedies, the nature of Peregrine's liability need not be considered further save to note that it was ultimately assessed to be the same as the liability of the law firm, which also had not shared in the secret profit. The second class consisted of Treit, Wilkins and their respective corporations. The members of this class had breached their fiduciary duties and had taken a secret profit. The third class was constituted by Wollen and his law firm, which had breached its fiduciary duties to the plaintiffs but had not shared in the secret profit. To the third class of defendants, Boughton can be added as a member. The significance of his membership will be explained below, but for present purposes, all that needs to be noted is that the trial judge, Paris J., stated that Boughton's liability had been fully canvassed and, if necessary, the pleadings could be amended to allege Boughton's knowledge of the secret profit and the law firm's liability through his actions. ${ }^{30}$

The assessment of the liability of the second class, the guilty profiteers, was, relatively speaking, straightforward. It is a well-established principle of equity that a trustee or fiduciary must disgorge his or her secret profits even if the beneficiary of the trust or fiduciary duty would not or could not have secured that profit. ${ }^{31}$ Indeed, secret or not, equity requires a trustee or fiduciary to account for any profits earned from the equitable relationship unless the beneficiary has given a fully informed consent to the trustee or fiduciary acting in his or her own interest with a view to making a profit. ${ }^{32}$ This approach to the disgorgement of profits is another example of the remedial generosity of equity and its strictness against trustees and fiduciaries.

Focusing on the guilty profiteers in Canson, the members of this class of defendants were liable for at least $\$ 115,000$, which was the measure of their secret profit. Next, in accordance with the judgment affirmed by the Supreme Court in the first phase of the action, the guilty profiteers were liable for consequential losses excluding losses caused by the engineer and the pile-driving contractor. The consequential losses included a portion of property taxes paid by the plaintiffs until the warehouse lands were lost by foreclosure and compensation for their carrying costs or for the loss of the

Canson cited to [1993] I W.W.R. 386, supra note 5 at 397.

Canadian Aero Services Ltd. v. O'Malley (1973), 40 D.L.R. (3d) 37 (S.C.C.).

Keech v. Sanford (1726), 25 E.R. 233 (Ch. D.); Regal (Hastings Led.) v. Gulliver, [1942] ! All E.R. 378 (H.L.); Boardman v. Phipps, [1967] 2 A.C. 46 (H.L.); Baillie v. Charman (1992), 94 D.L.R. (4th) 403 (B.C.C.A.). 
use of money tied up in the property. Consequential losses may also have included a small amount for some wasted project expenses, but the evidence was not clear on this claim. The plaintiffs were also entitled to pre-judgment interest, which award involved some intricate points about British Columbia's Court Order Interest Act. ${ }^{33}$

The assessment of the liability of the third class, Wollen and his law firm, was anything but straightforward. Wollen and the firm were liable for the consequential damages and for, at least, $\$ 22,500$ of the loss associated with the purchase of the lands. The foundation for the liability thus far can be explained by the following line of argument that emerges from Paris J.'s judgment. Wollen and his firm had a fiduciary relationship with the clients Canson and Fealty; indeed, this was conceded. The firm, through Wollen, breached its fiduciary duty because Wollen should not have taken for granted that the intervening transaction was proper and known to all the joint venturers. Wollen's failure to inquire about the oddity of his clients' paying an apparent $\$ 115,000$ premium for the Henderson lands was also professional negligence. Alternatively, whether or not Wollen knew about the impropriety of the intervening sale, his partner Boughton knew about it and about the secret profit. Boughton, in his capacity as a member of the law firm acting for Canson and Fealty, had a fiduciary obligation to disclose this information because his knowledge was part of the collective knowledge of the firm and he had a potential conflict of interest because of his personal stake in the transaction. ${ }^{34}$ Thus, the firm was liable for breach of fiduciary duty and professional negligence either through Wollen or through Boughton.

Next, the line of argument continues, it was established on the evidence that, but for the breach of fiduciary duty, the plaintiffs would not have purchased the Henderson property. In any event, it was a principle of equity (and yet another example of equity's restitutionary generosity) that when a fiduciary fails to disclose material facts and a loss is suffered, the guilty fiduciary bears the onus of proving that disclosure would not have made any difference to the victim. ${ }^{35}$ In other words, when there is a breach of fiduciary duty, the court will not speculate about what the beneficiary would have done if properly advised. In Paris J.'s view, the measure of the compensation for the law firm's breach of fiduciary duty should be measured by the nature of the wrong suffered by entering into the transaction that would otherwise have been avoided. Following the directions of the courts in the first phase of the action, this measure of compensation was similar to the measure of damages for fraud, where the victim is entitled to the difference in value between the purchase price and the market value of the goods purchased plus consequential losses. ${ }^{36}$ Thus, Wollen and his law firm were liable for the consequential damages and for $\$ 22,500$, which was the plaintiffs' share of the overpayment for the lands.

$1 \quad$ R.S.B.C. 1996, c. 78.

" Davey v. Woolley. Hames, Dale \& Dingwall (1982), 35 O.R. (2d) 599 (C.A.).

"s Brickenden v. London Loan \& Savings Co., [1934] 3 D.L.R. 465 (P.C.); Commerce Capital Trust Co. v. Berk (1989), 57 D.L.R. (4th) 759 (Ont. C.A.).

u. Jack v. Davis (1982), 14! D.L.R. (3d) 355 (B.C.C.A.); Doyle v. Olby (Ironmongers) Ltd., [1969] 2 Q.B. 158 (C.A.). 
The most contentious issue was whether Wollen and the law firm were liable for the balance of the claim associated with the $\$ 115,000$ secret profit, recognizing that the evidence established that Wollen had not known about the secret profit and that neither he nor his law firm had taken any share of it. For the trial judgment, Paris J. simply said that if the law firm had shared in the secret profit, then it would have had to disgorge the secret profit, but this was not the case and so the firm was not liable. On their appeal of Paris J.'s judgment, Canson and Fealty offered a new argument as to why Wollen and his firm should be liable for the secret profit earned by the other defendants. They relied on the Supreme Court's decision in Re Air Canada and M\&L Travel Lid., ${ }^{37}$ which concerned equity's ability to extend liability for breach of trust or fiduciary duty beyond the guilty trustees to so-called intermeddlers or strangers to the trust or fiduciary duty. The plaintiffs in Canson argued that, although Wollen and the law firm had not shared in the ill-gotten gains, their knowledge and involvement in facilitating those gains made them liable under the doctrine of knowing assistance. Before discussing the British Columbia Court of Appeal's response to this argument, it is necessary to turn to the Air Canada case and to its discussion of knowing assistance.

The bare facts of the Air Canada case were that a travel agency was obliged to hold the proceeds from its sale of Air Canada tickets in trust for the airline, but the agency breached its trust and used the proceeds to reduce its indebtedness to a bank. The issue in the case was whether the directors and owners of the travel agency were also liable to Air Canada for their travel agency's breach of trust. Air Canada claimed that the directors were liable as a trustee de son tort, or under the doctrine of knowing assistance, or the doctrine of knowing receipt, all doctrines that extend equity's remedial power to award compensation.

lacobucci J. wrote the main judgment of the court. ${ }^{38}$ He explained that equity had several doctrines upon which a stranger to a trust or fiduciary duty could be held liable for breach of trust or fiduciary duty. ${ }^{39}$ These doctrines had been discussed and differentiated in the old English case of Barnes v. Addy, ${ }^{40}$ but there were controversial problems about each of the doctrines and courts in Canada and in England had diverged in attempting to resolve the problems and in rationalizing the principles. ${ }^{41}$ As he went

Supra nole 9.

3k I, Forest, Sopinka, Gonthier, Cory, and Major JJ. concurred with lacobucci J. McLachlin J. concurred with the result but felt that the case could be decided narrowly without venturing to decide some of the difficult legal and policy issues raised in lacobucci J.'s judgment.

The equitable doctrines may apply to both breaches of trust and also to breaches of fiduciary duty. See P.D. Finn, "The Liability of Third Parties for Knowing Receipt or Assistance" in D.W.M. Waters, ed., Equity. Fiduciaries and Trusts (Toronto: Carswell, 1993) 195 at 200-201, 204-205; C. Harpum "The Stranger as Constructive Trustec" (1986) I02 L.Q.R. 114 at I14; and D.W.M. Waters, Law of Trusts in Canada, 2d ed. (Toronto: Carswell, 1984) at 381. (1874), L.R. 9 Ch. App. 244.

" R.B. Grantham \& C.E.F. Rickett, "Liability for Interfering in a Breach of Trust" (1998) I14 L.Q.R. 357: L. Smith, "Whither Knowing Receipt?" (1998) II4 L.Q.R. 394; S. Gardner, "Knowing Assistance and Knowing Receipt: Taking Stock" (1996) 112 L.Q.R. 56; T. Allan, "Fraud, Unconscionability and Knowing Assistance" (1995) 74 Can. Bar Rev. 29; M.H. Ogilvie, "Case Comment - Arthur Anderson Inv. v. Toronto Dominion Bank" (1994) 73 Can. Bar Rev. 592; E.P. 
along in his judgment, lacobucci J. confronted some of these problems and he articulated the response of Canadian law. He explained that when a person who, although not appointed a trustee, goes ahead to possess and administer trust property and to act as a trustee, the person will be liable as a trustee de son tort, if he or she commits a breach of trust. ${ }^{42}$ This type of liability, however, did not arise in Air Canada because the directors of the travel agency did not personally take possession of trust property or assume the function of trustees. Second, a stranger to a trust or fiduciary duty could be liable under the doctrine of knowing receipt if the stranger received property in his or her own personal capacity (that is, beneficially and not merely as agent of the guilty trustee) with actual or constructive knowledge of a breach of trust or fiduciary duty. This type of liability did not arise in Air Canada because the directors of the travel agency did not personally receive the ticket proceeds, ${ }^{43}$ and liability for knowing receipt requires that the stranger receive or apply the property for his or her own use and benefit. ${ }^{44}$ Third, a stranger to a trust or fiduciary duty could be liable for breach of trust or fiduciary duty if he or she knowingly assisted the trustee or fiduciary in a dishonest and fraudulent scheme. The basis for liability had come to be known as the doctrine of knowing assistance. This third type of liability did potentially arise in Air Canada, but there were two controversial points: the nature of the knowledge requisite for the stranger's liability, and the nature of the breach of trust or fiduciary duty requisite for the stranger's liability.

On the first controversial point about knowing assistance, lacobucci $\mathrm{J}$. held that constructive knowledge, that is, knowledge of circumstances which would put an honest person on inquiry, was insufficient for liability under the doctrine of knowing assistance. It was insufficient because where the stranger takes no benefit from the transaction, constructive notice did not amount to the want of probity that would attract equity's interest as a court of conscience. ${ }^{\text {is }}$ Put somewhat differently, equity's

Ellinger, "The Bank as Fiduciary and Constructive Trustce" (1994) 9 B.F.L.R. 111; Finn, supra note 39 at 195; P.J. Millet,, "Tracing the Proceeds of Fraud" (1991) 107 L.Q.R. 71; K. Kalinowsky, "The Constructive Trustec: A Stranger's Knowing Participation in the Breach of Trust" (1991) 7 B.F.L.R. 383; P.L. Loughlan, "Liability for Assistance in a Breach of Fiduciary Duty" (1989) 9 Oxford J. of Legal Studies 260; R. Sullivan, "Strangers to the Trust" (1986) 8 Est. \& Tr. Q. 217; Harpum, supra note 39 al 114, 267. v. Browne, [1896] I Ch. 199 at 209; Lyell v. Kennedy (1889), 14 App. Cas. 437 (H.L.); Soar v. Ashuell, [1893] 2 Q.B. 390 (C.A.); Royal Bank of Canada v. Fogler, Rubinoff (1991), 5 O.R. (3d) 734 (C.A.); Maguire v. Maguire and Toronto General Trusts Corporation (1921), 64 D.L.R. 204 (Ont. S.C.).

st As discussed below, one of the controversial problems associated with knowing receipt cases is whether constructive knowledge is sufficient to ground liability. The answer from Gold $\mathbf{v}$. Rosenberg, supra note 10 and Citadel General Assurance Co. v. Lloyds Bank Canada, supra note 10 is yes. Another controversy concerns the doctrinal basis of the claim. The answer from Gold and Citadel General is that the claim is a manifestation of unjust enrichment. Igip (Africa) Lid. v. Jackson, [1990] I Ch. 265 (Ch. D.), affd [1992] 4 All E.R. 451 (C.A.). Unjust enrichment would be stretched out of shape as the doctrinal basis for the stranger's liability for knowing assistanee because the stranger may not have enjoyed any enrichment and, rather, only assisted in the enrichment of the guilty trustee or fiduciary. Liability for knowing assistance can be better explained as equity's counterpart to the tort of conversion because it responds to interference with the plaintiff's property. See Grantham and Smith, supra note 41. 
intervention was justified only if the stranger's conscience was sufficiently engaged so as to justify the imposition of personal liability ${ }^{46}$ lacobucci J. stated: "The knowledge requirement for this type of liability is actual knowledge, recklessness or willful blindness will also suffice." ${ }^{47}$ Iacobucci J. explained that for liability, the stranger had to have this degree of knowledge about both the existence of the trust and also about the breach of it. Where the trust was imposed by statute, then the stranger would be deemed to have actual knowledge of its existence. If the stranger received a benefit, then this might ground an inference that the stranger had actual knowledge.

As for the nature of the breach of trust or breach of fiduciary duty requisite for the stranger's liability, which was the second point of controversy, there was a divergence in the authorities, but lacobucci J. held that under the doctrine of knowing assistance, the quality of the breach made a difference and equity's imposition of liability upon the stranger was justified only if the trustee's or fiduciary's breach was dishonest and fraudulent in the sense of being morally reprehensible. A trustee would be acting dishonestly or fraudulently if he or she took on a risk to the prejudice of another's rights. Applying lacobucci J.'s resolution of these points to the facts of the Air Canada case leads to the conclusion that the travel agency had committed a dishonest and fraudulent breach of trust. In turn, the directors actually knew about the breach, had participated in its occurrence and, therefore, were liable under the doctrine of knowing assistance.

With this background, the discussion can return to the British Columbia Court of Appeal's judgment in the second phase of Canson and its consideration of knowing assistance as the basis for a claim against Wollen and his firm. The court's judgment was written by Rowles J.A., and he said that the question was whether the principles of Air Canada applied where the stranger was a solicitor who did not receive any benefit from what was clearly a fraudulent and dishonest act by the parties to the secret profit. In these circumstances, for the solicitor to be liable for knowing assistance, the solicitor would have to have had actual knowledge of both the existence of the fiduciary duty and the dishonest act. These circumstances would provide a justification for making Wollen and the law firm, who did not share in the secret profits, liable for more than the $\$ 22,500$ overpayment for the property. However, Rowles J.A. noted that Paris J. had held that Wollen did not have actual knowledge of misconduct, and therefore he could not be held personally liable for the secret profits.

This far, Rowles J.A.'s reasoning seems sound; however, the continuation of his reasons, where he addressed the question of whether the law firm might be liable because of Boughton's actual knowledge of the secret profit, is problematic. Rowles J.A. reasoned that for the law firm to be liable because of Boughton's knowledge, it would be necessary to impute Boughton's knowledge to Wollen, but even if that were done, Wollen's knowledge would be constructive and not the actual knowledge required to ground liability for knowing assistance. One problem with this line of reasoning, however, is that no imputation of knowledge was necessary. Boughton himself was a 
member of the law firm and his actual knowledge was part of the collective knowledge of the law firm. Further, if Rowles J.A.'s reasoning was correct, it would have the somewhat anomalous result that the law firm would be held liable for breach of fiduciary duty because of Boughton's failure as a member of the firm to disclose his knowledge of the secret profit, but the firm would not be liable for knowing assistance notwithstanding Boughton's actual knowledge of the secret profit.

Therefore, it would seem that the law firm did have actual knowledge through Boughton, and Canson and Fealty's argument might well have succeeded. If the plaintiffs' argument on the appeal had succeeded, then the second phase of the Canson case would have provided an example of the remedial power and generosity of equity under its doctrine of knowing assistance because a party technically a stranger to a fiduciary duty and who had not personally benefited from its breach would nevertheless have been liable to pay compensation equal to the plaintiffs' share of the secret profit secured from the breach of fiduciary duty. As it stands, although there may arguably have been an error about the state of the law firm's knowledge, the second phase of Canson teaches the lessons that liability under the doctrine of knowing assistance depends upon the stranger having actual knowledge of a morally culpable breach of equitable duty and that constructive knowledge is insufficient.

\section{RESTITUTION AND KNOWING RECEIPT}

With a little reflection, there are more lessons to be learned from the Canson case about the scope of equity's remedial generosity and power. The reflection begins with the insight that the courts in both phases of the action seem to have been responding to the feature that Wollen and his law firm had not personally gained from the flip of the Henderson property and, in these circumstances, some limits on equity's generosity seemed necessary. This insight explains the importance of actual knowledge of a morally culpable breach to the doctrine of knowing assistance. The stranger's participation with actual knowledge of the fraudulent or dishonest conduct provides the want of probity that justifies equity exercising its in personam jurisdiction to make the stranger compensate the beneficiary.

The reflection continues by asking whether the outcome of the second phase of Canson might have been different had the firm received a benefit. For example, what would the result have been if it were assumed that Wilkins or Treit owed the law firm $\$ 50,000$ and that they used part of their secret profits to retire this indebtedness? This assumption leads to a discussion of the line of Supreme Court of Canada's decisions that developed from the Air Canada case. In Gold v. Rosenberg ${ }^{48}$ and Citadel General Assurance Co. v. Lloyds Bank Canada ${ }^{49}$ the court returned to the principles of the Air Canada case and to the topic of the nature of the liability of strangers for a breach of trust or breach of fiduciary duty. 
It is convenient to begin the discussion with the Citadel case. In this case, D Ltd. was an agent that sold Citadel's insurance policies. D Ltd. deposited the premium payments into its account at Lloyds Bank. In June 1987, IW Ltd., D Ltd.'s parent corporation, instructed the bank that the funds in D Ltd.'s account were to be transferred into IW Ltd.'s account at the end of each business day. The transfer was beneficial to the bank because it reduced IW Ltd.'s indebtedness to the bank. The transfer, however, was a breach of trust by D Ltd. and detrimental to Citadel because, when D Ltd.'s business failed, it had no funds to pay Citadel $\$ 633,622.84$ for unremitted insurance premiums. The Supreme Court of Canada, reversing the decision of the Alberta Court of Appeal and restoring the trial judgment, held that Lloyds Bank, although technically a stranger to any trust or fiduciary duty owned Citadel, was liable under the doctrine of knowing receipt.

La Forest $\mathbf{J}$. wrote the main judgment for himself and five other justices of the seven-member panel. ${ }^{\text {so }}$ Sopinka J. wrote short concurring reasons. ${ }^{51}$ La Forest $\mathrm{J}$. explained that the bank was not liable as a trustee de son tort because it never assumed the office of trustee and it was not liable under the doctrine of knowing assistance because, as established in the Air Canada case, actual knowledge was a requisite element and the bank had not known that the transfer of funds into the parent corporation's bank account was a breach of trust. Similarly, the bank was also not liable under what La Forest J. described as the doctrine of knowing dealing, an equitable doctrine under which a person who, after lawfully receiving trust property without any personal benefit, will be liable if he or she deals with the trust property in a manner known to be inconsistent with the trust. ${ }^{52}$

However, the bank was liable under the doctrine of knowing receipt because it had received funds for its own benefit and, in these circumstances, constructive knowledge, that is, knowledge of facts sufficient to put a reasonable person on notice or inquiry, is sufficient to ground liability. La Forest J.'s judgment makes it clear that the doctrinal rationale for liability for knowing receipt is different from the rationale for liability for knowing assistance and the receipt of a personal benefit justifies the imposition of liability based on the lower standard of constructive knowledge. Constructive knowledge, which is all that is required for knowing receipt, is a lower standard because it is easier to prove what a person ought to know than what he or she actually knows. The knowing recipient must disgorge or return his or her benefit and restore to the plaintiff because the knowing recipient purported to enrich himself or herself at the plaintiff's expense. ${ }^{33}$ This self-interest demands that the recipient take care that others are not being harmed. In contrast, the doctrinal basis for recovery under the doctrine of knowing assistance does not depend on the defendant being enriched, rather, equity

Gonthicr, Cory, McLachlin, lacobucci, and Major JJ. concurred.

"Sopinka J. concurred but subject to his reasons in the companion case of Gold v. Rosenberg, supra note 10 at 404.

32 La Forest J. seems to have been using a classification scheme similar to that suggested by Harpum, supra note 39 at $114,267$.

st See also lacobucci J.'s dissenting judgment in Gold v. Rosenterg, supra note 10 at $395-99$ where he develops the point that unjust enrichment is the essence of a claim for knowing receiph, which is not a fault-based claim. 
intervenes because the defendant actually knew that he or she was an accessory to reprehensible conduct by the trustee or fiduciary. The absence of a personal benefit as an element under knowing assistance justifies the higher standard of actual knowledge. In the Citadel case, La Forest J. stated:

In "knowing reccipt" cases, relief flows from the breach of a legally recognized duty of inquiry. More specifically, relief will be granted where a stranger to the trust, having received trust property for his or her own benelit and having knowledge of facts whicl would put a reasonable person on inquiry, actually fails to inquire as to the possible misapplication of trust property. It is this lack of inquiry that renders the recipient's enrichment unjust."

Turning now to Gold v. Rosenberg, in this case, the defendant Rosenberg, who was an executor and a beneficiary of his father's estate, arranged to have a corporation owned by the estate sign a guarantee to repay his own corporation's indebtedness to the Toronto Dominion Bank. The guarantee was secured by a mortgage of estate property. The plaintiff Gold, who was a co-executor and beneficiary, authorized the transaction but later said he had been misled and he sued the bank for a declaration that the guarantee was invalid. In a four to three split judgment, which affirmed the judgment of the Ontario Court of Appeal, the Supreme Court dismissed Gold's action. In the main judgment, Sopinka J. for a majority ${ }^{35}$ agreed with that portion of lacobucci J.'s dissenting judgment ${ }^{56}$ which dismissed Gold's claim under the doctrine of knowing assistance. This claim failed because there was no proof that the bank had actual knowledge of Rosenberg's dishonest and fraudulent breach of trust. In Sopinka J.'s majority opinion, Gold's claim under the doctrine of knowing receipt also failed because, in the circumstances of the case, the bank had acted reasonably and did not have either actual or constructive notice of any breach of trust. Sopinka J., felt that an honest person would not have acted any differently than the bank."

With this background from Citadel and Gold, it is now possible to consider the question posed above that was premised on a variation of the facts in the Canson case. This variation would have the law firm obtain a benefit from the breach of fiduciary duty by the other defendants. In these circumstances, the answer is that the law firm would appear to be liable under the equitable doctrine of knowing receipt because it is most likely that the remaining constituent element of at least constructive notice of the breach of fiduciary duty would have been satisfied. In this last regard, it is to be recalled that the various courts were prepared to find the law firm professionally negligent based on the knowledge of either Wollen or Boughton, and their knowledge individually or taken together would likely be sufficient to put an honest person on

44 Citadel, supra note 10 at 434.

ss McLachlin and Major JJ. concurring. Gonthier J. concurring in short separate reasons.

36 La Forest and Cory JJ. concurred in the dissent.

37 Sopinka, Mclachlin, and Major JJ. also felt that the claim for knowing receipt failed because, in their view, the receipt of a guarantee backed by a mortgage was not a beneficial receipt of property. On this point, however, Gonthier J. agreed with lacobucci, La Forest, and Cory JJ. Thus, Gonthier J. decided that it was a knowing receipt case but the constituent element of at least constructive knowledge had not been satisfied. 
inquiry. Moreover, Paris $\mathrm{J}$. had already concluded that it was professional negligence for Wollen not to have made inquiries.

If these conclusions are correct and the firm was liable for knowing receipt, it is worth noting that the firm's unjust enrichment, that is, the extent of the benefit it received, both explains and also demarcates the limits of its liability. In other words, the firm must disgorge the unjust benefit it received with constructive knowledge of a breach of trust or fiduciary duty. In terms of the hypothetical facts, this would mean that the firm would be liable to return the $\$ 50,000$ it received but it would not be liable to restore to the plaintiffs the balance of the secret profit earned by the other defendants. In contrast, if the law firm had been found liable for knowing assistance, it would be liable for some part of the secret profit. In addition to illustrating the complexities of the various potential equitable remedies against the law firm that might variously justify awards of $\$ 25,500$ (compensation for breach of fiduciary duty), $\$ 50,000$ (compensation for knowing receipt), or $\$ 86,250$ (compensation for knowing assistance), the lesson from this hypothetical version of the Canson facts is that the constituent elements of knowing receipt may be easier to prove than the elements of knowing assistance, but the recovery from proving knowing receipt may be less than the recovery for proving knowing assistance.

\section{Conclusion}

It is now possible to quickly conclude by introducing a practical factor that was omitted from the overview of the procedural history and factual background to Canson Enterprises Ltd. v. Boughton. This factor explains the great attention paid to the nature of the liability of Wollen, Boughton and their law firm. The practical reality of the Canson case was that the other defendants were without the financial means to compensate the plaintiffs. Wilkins had died without assets. Sun-Mark had been struck from the register of companies and had no assets. Peregrine's fate had been similar. Treit and his companies settled for $\$ 40,000$, presumably because that was all that the plaintiffs could extract from them. As already noted, the soils engineer and the pile-driving contractor were without means. This factor also explains the comments made at the outset of this article about the power and allure of equity's remedies. 